\title{
Clickable azide-functionalized bromoarylaldehydes - synthesis and photophysical characterization
}

\author{
Dominik Göbel ${ }^{1}$, Marius Friedrich ${ }^{1,2}$, Enno Lork ${ }^{3}$ and Boris J. Nachtsheim ${ }^{* 1}$
}

\section{Full Research Paper}

\section{Address:}

${ }^{1}$ Institute for Organic and Analytical Chemistry, University of Bremen, Leobener Straße 7, 28359 Bremen, Germany, ${ }^{2}$ Department of Organic Chemistry, Technical University Kaiserslautern, Erwin-Schrödinger-Straße Geb.54, 67663 Kaiserslautern, Germany and ${ }^{3}$ Institute for Inorganic and Crystallographic Chemistry, University of Bremen, Leobener Straße NW2, 28359 Bremen, Germany

\section{Email:}

Boris J. Nachtsheim* - nachtsheim@uni-bremen.de

* Corresponding author

\section{Keywords:}

bromoarylaldehydes; click-chemistry; fluorenes; fluorescence;

phosphorescence
Beilstein J. Org. Chem. 2020, 16, 1683-1692.

doi:10.3762/bjoc.16.139

Received: 11 May 2020

Accepted: 30 June 2020

Published: 14 July 2020

This article is part of the thematic issue " $\mathrm{C}-\mathrm{H}$ functionalization for materials science".

Guest Editor: K. Itami

(C) 2020 Göbel et al.; licensee Beilstein-Institut.

License and terms: see end of document.

\begin{abstract}
Herein, we present a facile synthesis of three azide-functionalized fluorophores and their covalent attachment as triazoles in Huisgen-type cycloadditions with model alkynes. Besides two ortho- and para-bromo-substituted benzaldehydes, the azide functionalization of a fluorene-based structure will be presented. The copper(I)-catalyzed azide-alkyne cycloaddition (CuAAC) of the so-synthesized azide-functionalized bromocarbaldehydes with terminal alkynes, exhibiting different degrees of steric demand, was performed in high efficiency. Finally, we investigated the photophysical properties of the azide-functionalized arenes and their covalently linked triazole derivatives to gain deeper insight towards the effect of these covalent linkers on the emission behavior.
\end{abstract}

\section{Introduction}

Small organic luminophores exhibiting room-temperature phosphorescence (RTP) have attracted great attention due to promising applications in optoelectronic devices [1-8], biological imaging [9-12] and chemical sensing [13-15]. Referring to the Jablonski diagram (see Scheme 1a) [16,17], upon excitation from the singlet ground state $\left(\mathrm{S}_{0}\right)$ to higher singlet states $\left(\mathrm{S}_{\mathrm{n}}\right)$, followed by internal conversion (IC), either non-radiative or radiative decay to $S_{0}$ can occur. While the latter decay (fluores- cence) takes place without a change in the electron spin, phosphorescence is defined as the radiative transition from the lowest excited triplet state $\left(\mathrm{T}_{1}\right)$ to the singlet ground state $\left(\mathrm{S}_{0}\right)$ [18-21]. Triplet state excitons are generated by the spinforbidden intersystem crossing (ISC) process from the first excited singlet state $\left(S_{1}\right)$. Pursuant to the El-Sayed rule (see Scheme 1b) [22,23], ISC is spin allowed from ${ }^{1}\left(n, \pi^{*}\right)$ to ${ }^{3}\left(\pi, \pi^{*}\right)$ and from ${ }^{1}\left(\pi, \pi^{*}\right)$ to ${ }^{3}\left(\mathrm{n}, \pi^{*}\right)$ excited states, while ISC is spin- 


\section{a)}

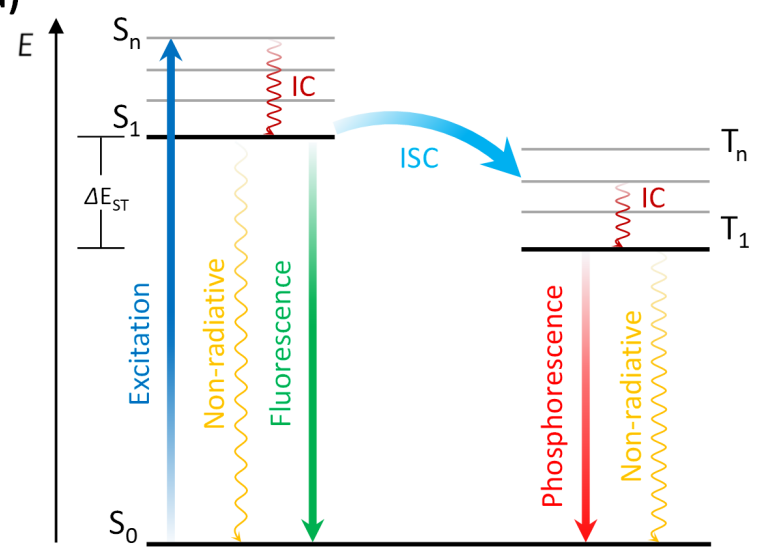

b)

\section{El-Sayed Rule}

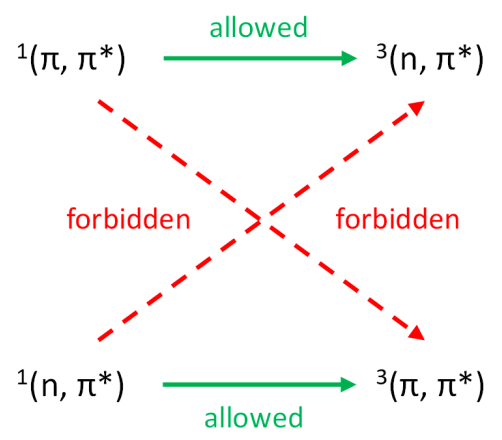

Scheme 1: a) Schematic depiction of the Jablonski diagram b) Schematic representation of El-Sayed's rule.

forbidden from ${ }^{1}\left(\mathrm{n}, \pi^{*}\right)$ to ${ }^{3}\left(n, \pi^{*}\right)$ and from ${ }^{1}\left(\pi, \pi^{*}\right)$ to ${ }^{3}\left(\pi, \pi^{*}\right)$ excited states, owing to the poor orbital overlap, resulting in a decreased spin-orbit coupling.

Quenching processes of triplet states, induced by molecular motions, oxygen, or humidity, restrict the versatile application of such organic materials [24]. Thus, low temperatures [25-27] or inert conditions [28] are necessary to facilitate an afterglow emission.

Most phosphorescence studies are focused on metal complexes due to a strong heavy atom-induced spin-orbit coupling [29-33]. Considering the high price and the toxicity of many metal complexes, pure organic phosphors are highly desirable $[16,17,34-$ 37]. Two approaches are applied to achieve organic phosphors: (1) introduction of nonmetal heavy atoms, such as halogens $(\mathrm{Br}$ or I) or functionalities containing lone pairs, in particular carbonyl groups, nitrogen, sulfur, and phosphorus derivatives which facilitate the ISC process from $S_{1}$ to $T_{n}$ and thus increase the spin-orbital coupling [38-47]. Also, decreasing the singlet-triplet splitting energy $\left(\Delta E_{\mathrm{ST}}\right)$ caused by intramolecular charge-transfer (ICT) interactions is an approved method $[48,49]$. (2) Significant reduction of non-radiative transitions can be achieved by the host-guest method [50-52] or by crystallization [53-57]. In difference to the liquid phase, the highly ordered packing and the restriction of molecular motions in the crystalline state favor a persistent luminescence.

The promotion of ISC processes through intermolecular halogen bonding to generate efficient RTP was initially investigated by Kim et al. [58]. They developed the minimalistic 2,5dihexyloxy-4-bromobenzaldehyde (1) [59-63] which showed a weak fluorescence in solution, but exhibited a green phosphorescence with a quantum yield of $\Phi_{\mathrm{P}}=2.9 \%$ in the crystalline state: this behavior was caused by intermolecular halogen bonds from the carbonyl-oxygen atom to an adjacent bromine atom (Figure 1a).

Despite multifarious examples of RTP in the crystalline state, purely organic compounds showing RTP in solution are rare [64-69]. Takeuchi et al. [28] reported a bromofluorenecarbaldehyde 2 which shows blue fluorescence in chloroform at $298 \mathrm{~K}$ under air and green phosphorescence under argon with a phosphorescence quantum yield of $\Phi_{\mathrm{P}}=5.9 \%$ (Figure $1 \mathrm{~b}$ ). This observation is reasoned by a strong $\left(\pi, \pi^{*}\right)$ character of the $T_{2}$ state.

Although phosphorescent organic compounds are well investigated with respect to their photophysical properties in the crystalline state, in solution or physically embedded in polymer matrices, there is a significant lack of possibilities [61] for their targeted covalent attachment to higher structures. This is due to missing synthetic strategies to incorporate suitable linkable functionalities into those luminophores.

Our group is highly interested in the de novo synthesis of small organic luminophores and in this regard, we recently developed efficient methods for the synthesis of ESIPT-based luminophores [70-72]. Herein, we present the efficient functionalization of derivatives of the potent luminophores $\mathbf{1}$ and $\mathbf{2}$ with "clickable" azide functionalities to target the structures 3-5 and further investigated the influence of this functionalization, both in the unlinked azide state and the linked triazole state, on the emission properties of these compounds (Figure 1).

\section{Results and Discussion Syntheses para- and ortho-bromobenzalde- hyde $\mathbf{3}$ and $\mathbf{4}$}

We initiated our synthetic investigations towards azide-functionalized para-bromobenzaldehyde $\mathbf{3}$ with a two-step sequence. Condensation with 2-amino-2-methylpropan-1-ol and oxidation 
literature examples:

a) Kim et al. [58]<smiles>CCOc1cc(Br)c(OCCCCCCCCCCCO)cc1Br</smiles>

1 b) Takeuchi et al. [28]

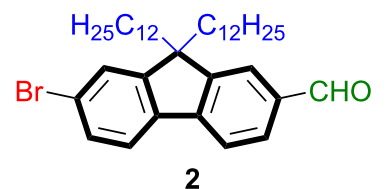

this work:<smiles>[N]Cc1cc(Br)ccc1C=O</smiles>

3<smiles>N#Cc1ccc(C=O)c(Br)c1</smiles>

4<smiles>CC1(C)c2cc(Br)ccc2-c2cc(CN)c(C=O)cc21</smiles><smiles>CC1(N)C2CCC1CC(CN)C2</smiles><smiles>C#CCC</smiles>

$[\mathrm{Cu}]$<smiles>OC1C2CC3CC1CC(Cn1cc(-c4ccccc4)nn1)(C3)C2</smiles>

Figure 1: Top: literature examples of organic compounds showing RTP in the crystalline state (a) and in solution (b). Bottom: azide-linked derivatives presented in this work.

with NBS yielded oxazoline 6 in a good yield. Directed orthometalation utilizing TMPMgCl$\cdot \mathrm{LiCl}$ under mild conditions and subsequent smooth formylation with DMF afforded benzaldehyde 7 (see Scheme 2). Due to rapid decomposition of 7 under ambient and acidic conditions, rapid aqueous work-up was conducted, followed by reduction with $\mathrm{NaBH}_{4}$, yielding the corresponding primary alcohol $\mathbf{8}$ in $81 \%$ yield over two steps. The transformation to azide $\mathbf{9}$ was accomplished by deprotonation using 1,8-diazabicyclo[5.4.0]undec-7-ene (DBU) and reaction with diphenylphosphoryl azide (DPPA) in excellent yield. Finally, the oxazoline group, which acted as directing and protecting group, was removed in a three-step sequence of $N$-methylation, reduction of the in situ formed iminium ion and acidic hydrolysis. This afforded the azide-functionalized parabromobenzaldehyde 3 in $78 \%$ yield and an overall yield of $56 \%$ (starting from 4-bromobenzaldehyde).

para-bromobenzaldehyde:<smiles>CC1(C)COC(c2ccc(Br)cc2)=N1</smiles>

6<smiles>CC1(C)COC(c2ccc(Br)cc2C=O)=N1</smiles>

7<smiles>[R]Cc1cc(Br)ccc1C1=NC(C)(C)CO1</smiles>

8: $\mathrm{R}=\mathrm{OH} \longrightarrow \mathrm{d}$ )<smiles>[NH3+]Cc1cc(Br)ccc1C=O</smiles>

3

ortho-bromobenzaldehyde:<smiles>Cc1ccc(C=O)cc1</smiles>

10

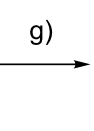<smiles>Cc1ccc(C2=NC(C)(C)CO2)c(Br)c1</smiles>

11<smiles>C=CC</smiles>

12: $\mathrm{R}=\mathrm{Br} \longrightarrow \mathrm{i})$
13: $\mathrm{R}=\mathrm{N}_{3} \longleftarrow \mathrm{i}$<smiles>[R]Cc1ccc(C2=NC(C)(C)CO2)c(Br)c1</smiles>

4

Scheme 2: Reaction conditions for para-bromobenzaldehyde 3: a) 1) 2-amino-2-methylpropan-1-ol, $4 \AA \mathrm{AS}^{\circ} \mathrm{CH}_{2} \mathrm{Cl}_{2}, 25{ }^{\circ} \mathrm{C}, 18 \mathrm{~h}$; 2 ) $\mathrm{NBS} \mathrm{CH}_{2} \mathrm{Cl}_{2}$, $25^{\circ} \mathrm{C}, 5 \mathrm{~h}, 91 \%$; b) 1) TMPMgCl-LiCl, THF, $25^{\circ} \mathrm{C}, 4 \mathrm{~h}$; 2) DMF, THF, $0{ }^{\circ} \mathrm{C}$ to $25^{\circ} \mathrm{C}, 1.5 \mathrm{~h}$; c) $\mathrm{NaBH} 4, \mathrm{THF} / \mathrm{MeOH} 1: 1 \mathrm{v} / \mathrm{v}, 0{ }^{\circ} \mathrm{C}, 1 \mathrm{~h}, 81 \%(2 \mathrm{steps})$; d) DPPA, DBU, PhMe, $25^{\circ} \mathrm{C}, 18 \mathrm{~h}, 98 \%$; e) 1) MeOTf, $\mathrm{CH}_{2} \mathrm{Cl}_{2}, 25^{\circ} \mathrm{C}, 2.5 \mathrm{~h}$; 2) $\left.\mathrm{NaBH}_{4}, \mathrm{THF} / \mathrm{MeOH} 4: 1 \mathrm{v} / \mathrm{v}, 0^{\circ} \mathrm{C}, 2.5 \mathrm{~h} ; 3\right)$ oxalic acid, THF/H $\mathrm{O}$ $4: 1 \mathrm{v} / \mathrm{v}, 25^{\circ} \mathrm{C}, 20 \mathrm{~h}, 78 \%$. Overall yield from 4-bromobenzaldehyde to $3: 56 \%$ (5 steps). Reaction conditions for ortho-bromobenzaldehyde 4: f) 1) 2-amino-2-methylpropan-1-ol, $4 \AA \mathrm{MS}, \mathrm{CH}_{2} \mathrm{Cl}_{2}, 25^{\circ} \mathrm{C}, 18 \mathrm{~h}$; 2) NBS, $\mathrm{CH}_{2} \mathrm{Cl}_{2}, 25^{\circ} \mathrm{C}, 4 \mathrm{~h}, 98 \%$; g) 1 ) TMPMgCl-LiCl, $\mathrm{THF}, 25^{\circ} \mathrm{C}, 4 \mathrm{~h}$; 2) $\left(\mathrm{CBrCl}_{2}\right)_{2}$, THF, $0{ }^{\circ} \mathrm{C}$ to $25{ }^{\circ} \mathrm{C}, 10 \mathrm{~h}, 76 \%$; h) NBS, AIBN, $\mathrm{CCl}_{4}, 100{ }^{\circ} \mathrm{C}, 7 \mathrm{~h}, 66 \%$; i) $\mathrm{NaN}_{3}, \mathrm{DMF}, 25{ }^{\circ} \mathrm{C}, 4 \mathrm{~h}, 99 \%$; j) 1$) \mathrm{MeOTf}^{\circ} \mathrm{CH}_{2} \mathrm{Cl}_{2}, 25{ }^{\circ} \mathrm{C}$, $2.5 \mathrm{~h}$; 2) $\mathrm{NaBH}_{4}, \mathrm{THF} / \mathrm{MeOH} 4: 1 \mathrm{v} / \mathrm{v}, 0^{\circ} \mathrm{C}, 2.5 \mathrm{~h}$; 3) oxalic acid, THF/ $\mathrm{H}_{2} \mathrm{O} 4: 1 \mathrm{v} / \mathrm{v}, 25^{\circ} \mathrm{C}, 20 \mathrm{~h}, 85 \%$. Overall yield from 4-methylbenzaldehyde to 4: $41 \%$ (5 steps). 
Azide-functionalized ortho-bromobenzaldehyde 4 was prepared by a similar route as aldehyde 3 . Initially, oxazoline formation from 4-methylbenzaldehyde yielded 2-aryloxazoline $\mathbf{1 0}$ in almost quantitative yield. The introduction of the orthobromine substituent was again accomplished by metalation using $\mathrm{TMPMgCl} \cdot \mathrm{LiCl}$ and subsequent reaction with 1,2-dibromotetrachloroethane to afford $\mathbf{1 1}$ in $76 \%$ yield. A second bromination at the benzylic position provided the dibrominated derivative 12 in $66 \%$ yield. The substitution reaction of benzyl bromide with sodium azide delivered the primary azide $\mathbf{1 3}$ in quantitative yield. Again, the final back-conversion of the oxazoline group to the corresponding aldehyde afforded azidefunctionalized ortho-bromobenzaldehyde 4 in $85 \%$ yield and an overall yield of $41 \%$ (starting from 4-methylbenzaldehyde).

\section{Bromofluorenecarbaldehyde 5}

The synthetic route to azide-functionalized 7-bromofluorene-2carbaldehyde 5 started from unfunctionalized fluorene. Double bromination to $\mathbf{1 4}$, followed by double methylation of the methylene bridge to $\mathbf{1 5}$ and a lithiation/formylation sequence afforded 7-bromofluorene-2-carbaldehyde 16 in excellent yield over three steps. Conversion to the 2-aryloxazoline 17 was accomplished in $92 \%$ yield using the same method as described for the synthesis of $\mathbf{6}$ and 10. ortho-Metalation with $\mathrm{TMPMgCl} \cdot \mathrm{LiCl}[70]$ and conversion of the magnesiated species with DMF to carbaldehyde $\mathbf{1 8}$ was followed by reduction with $\mathrm{NaBH}_{4}$ to give the primary alcohol 19. In contrast to benzaldehyde 7 , carbaldehyde $\mathbf{1 8}$ showed no decomposition at ambient temperature. While acidic hydrolysis of $\mathbf{1 9}$ provided exocyclic<smiles>Brc1ccc2c(c1)Cc1cc(Br)ccc1-2</smiles>

14<smiles>CC1(C)c2cc(Br)ccc2-c2ccc(Br)cc2C1(C)C(Cl)(Cl)Br</smiles>

15
16

d)<smiles>CC1(C)COC(c2cc3c(cc2CO)-c2ccc(Br)cc2C3(C)C)=N1</smiles>

19

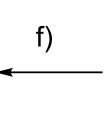<smiles>CC1(C)COC(c2cc3c(cc2C=O)-c2ccc(Br)cc2C3(C)C)=N1</smiles>

18

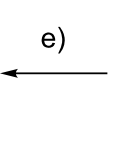<smiles>CC1(C)COC(c2ccc3c(c2)C(C)(C)c2cc(Br)ccc2-3)=N1</smiles>

17

g)<smiles>CC</smiles><smiles>CC1(C)c2cc(Br)ccc2-c2cc3c(cc21)C(=O)OC3</smiles>

20<smiles>CC1(C)COC(c2cc3c(cc2CN)-c2ccc(Br)cc2C3(C)C)=N1</smiles>

21

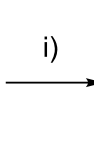<smiles>CC1(C)c2cc(Br)ccc2-c2cc(CN)c(C=O)cc21</smiles>

5

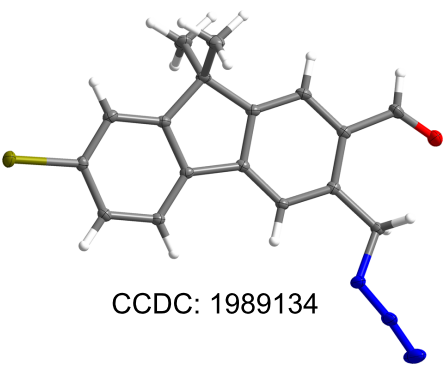

Scheme 3: Reaction conditions: a) $\mathrm{Br}_{2}$, Fe powder, $\mathrm{CHCl}_{3}, 0^{\circ} \mathrm{C}, 4 \mathrm{~h}, 99 \%$; b) $\mathrm{KOH}, \mathrm{KI}, \mathrm{Mel}, \mathrm{DMSO}, 25{ }^{\circ} \mathrm{C}, 18 \mathrm{~h}, 92 \%$; c) 1 ) $n$-BuLi, THF, $-78{ }^{\circ} \mathrm{C}$, $1 \mathrm{~h}$; 2) DMF, THF, $-78^{\circ} \mathrm{C}$ to $25^{\circ} \mathrm{C}, 10 \mathrm{~h}, 90 \%$; d) 1) 2-amino-2-methylpropan-1-ol, $\left.4 \AA \mathrm{MS}, \mathrm{CH}_{2} \mathrm{Cl}_{2}, 25^{\circ} \mathrm{C}, 18 \mathrm{~h} ; 2\right) \mathrm{NBS}^{\circ} \mathrm{CH}_{2} \mathrm{Cl}_{2}, 25{ }^{\circ} \mathrm{C}, 3 \mathrm{~h}, 92 \%$; e) 1) TMPMgCl-LiCl, THF, $25^{\circ} \mathrm{C}, 4 \mathrm{~h}$; 2) DMF, THF, $-15{ }^{\circ} \mathrm{C}$ to $25^{\circ} \mathrm{C}, 2 \mathrm{~h}$; f) $\mathrm{NaBH}_{4}$, THF/MeOH 1:1 v/v, $0{ }^{\circ} \mathrm{C}, 1.5 \mathrm{~h}, 79 \%$ (2 steps); g) $\mathrm{HCl}(4 \mathrm{~N})$, $120{ }^{\circ} \mathrm{C}, 6 \mathrm{~h}, 91 \%$; h) 1) DPPA, DBU, PhMe, $25{ }^{\circ} \mathrm{C}, 15 \mathrm{~h}$; 2) $\mathrm{NaN}_{3}$, PhMe, $60{ }^{\circ} \mathrm{C}, 4 \mathrm{~h}, 87 \%$; i) 1) $\mathrm{MeOTf} \mathrm{CH}_{2} \mathrm{Cl}_{2}, 25^{\circ} \mathrm{C}, 2.5 \mathrm{~h}$; 2) $\mathrm{NaBH} 4$, $\mathrm{THF} / \mathrm{MeOH}$ $4: 1 \mathrm{v} / \mathrm{v}, 0{ }^{\circ} \mathrm{C}, 2.5 \mathrm{~h}$; 3 ) oxalic acid, THF/ $\mathrm{H}_{2} \mathrm{O} 4: 1 \mathrm{v} / \mathrm{v}, 25{ }^{\circ} \mathrm{C}, 20 \mathrm{~h}, 86 \%$. Overall yield to $5: 45 \%$ (8 steps). The molecular structure of 5 shows $50 \%$ probability ellipsoids. 
$\gamma$-lactone 20, the substitution reaction with DPPA/ $\mathrm{NaN}_{3}$ yielded the primary azide in $87 \%$ yield. In accordance to previous deprotection reactions, fluorene $\mathbf{2 1}$ was converted by means of a three-step sequence to the desired azide-functionalized 7-bromofluorene-2-carbaldehyde 5 in 86\% yield and an overall yield of $45 \%$ (starting from fluorene). The molecular structure of 5 could be verified by X-ray diffraction (XRD, see Scheme 3).

\section{Derivatization of fluorenyl methanol 19}

To gain deeper insights into the emission behavior of fluorenes bearing different functional groups in the side chains, fluorenylmethanol 19 was subjected to derivatization reactions (see Scheme 4). Deprotonation and subsequent methylation afforded methoxy derivative $\mathbf{2 2}$, which was then converted into the methoxy-functionalized 7-bromofluorene-2-carbaldehyde $\mathbf{2 3}$ in $75 \%$ yield. Implementation of potent leaving groups in the side
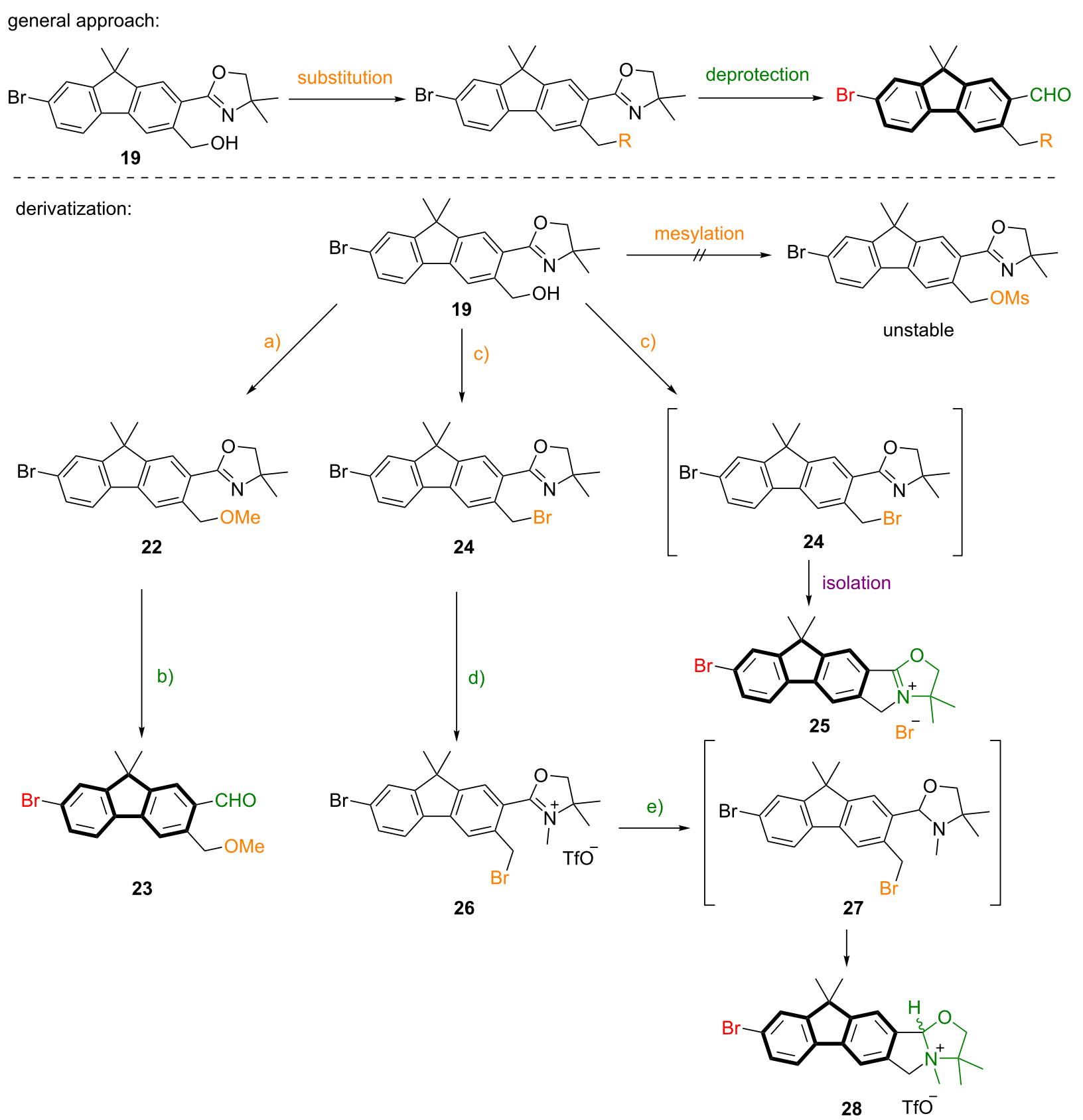

Scheme 4: Reaction conditions: a) 1) $\mathrm{NaH}$, THF, $0{ }^{\circ} \mathrm{C}, 30 \mathrm{~min}$; 2) Mel, THF, $0{ }^{\circ} \mathrm{C}$ to $25^{\circ} \mathrm{C}, 2 \mathrm{~h}, 99 \%$; b) 1$) \mathrm{MeOTf} \mathrm{CH}_{2} \mathrm{Cl}_{2}, 25{ }^{\circ} \mathrm{C}, 3 \mathrm{~h}$; 2$) \mathrm{NaBH}$ $\mathrm{THF} / \mathrm{MeOH}$ 4:1 v/v, $0^{\circ} \mathrm{C}, 3 \mathrm{~h}$; 3) oxalic acid, THF/ $\mathrm{H}_{2} \mathrm{O} 4: 1 \mathrm{v} / \mathrm{v}, 25^{\circ} \mathrm{C}, 24 \mathrm{~h}, 75 \%$. Overall yield from fluorene to $\left.23: 44 \%(8 \mathrm{steps}) . \mathrm{c}\right) \mathrm{CBr} 4, \mathrm{PPh}_{3}$, $\mathrm{CH}_{2} \mathrm{Cl}_{2}, 0^{\circ} \mathrm{C}$ to $25^{\circ} \mathrm{C}, 2 \mathrm{~h}, 95 \%$; or NBS, $\mathrm{PPh}_{3}, \mathrm{CH}_{2} \mathrm{Cl}_{2}, 0{ }^{\circ} \mathrm{C}$ to $25^{\circ} \mathrm{C}, 2 \mathrm{~h}, 91 \%$; or $\mathrm{PBr}_{3}, \mathrm{CH}_{2} \mathrm{Cl}_{2}, 0{ }^{\circ} \mathrm{C}$ to $\left.25^{\circ} \mathrm{C}, 2 \mathrm{~h}, 92 \% ; \mathrm{d}\right) \mathrm{MeOTf}^{\circ} \mathrm{CH}_{2} \mathrm{Cl}_{2}$, $25{ }^{\circ} \mathrm{C}, 3 \mathrm{~h}$; e) $\mathrm{NaBH}_{4}, \mathrm{THF} / \mathrm{MeOH} 4: 1 \mathrm{v} / \mathrm{v}, 0{ }^{\circ} \mathrm{C}, 3 \mathrm{~h}$. Overall yield from 24 to 28: $56 \%$ (2 steps). 
chain as complement linkable functionalities via $S_{N^{-}}$-reaction was initiated by mesylation. Unfortunately, the mesylated fluorene showed such a high reactivity that rapid decomposition occurred. However, bromination was conducted by various substitution methods delivering benzyl bromide $\mathbf{2 4}$, which upon isolation cyclized to iminium bromide $\mathbf{2 5}$ in high yield. To suppress this unexpected cyclization, careful fine-adjustment of the work-up conditions were made. Here, upon complete formation of $\mathbf{2 4}$, rapid filtration of the reaction mixture through a plug of neutral alumina, solvent evaporation and quick conversion in the next step was successfully applied. Deprotection to the carbaldehyde was performed using the well applied three-step methylation/reduction/hydrolysis sequence. Methylation of the oxazoline nitrogen afforded iminium salt $\mathbf{2 6}$, which was reduced to oxazolidine 27. Again, similar to 25, cyclization took place and ammonium triflate $\mathbf{2 8}$ was isolated in $56 \%$ yield (starting from 24). In contrast to the cyclization of oxazoline $\mathbf{2 4}$, oxazolidine 27 cyclized already during the reaction, caused by the increased basicity of the ring nitrogen.

\section{CUAAC reactions of bromocarbaldehydes}

We further investigated the reactivity of azide-functionalized bromocarbaldehydes 3, 4, and 5 in copper(I)-catalyzed azide-alkyne cycloaddition reactions (CuAAC). For this, we treated the azide-functionalized luminophores with alkynes exhibiting different degrees of steric demand, including 1-decyne (29), phenylacetylene (30), 1-ethynyladamantane (31) and 1,3di-tert-butyl-5-ethynylbenzene (32, see Scheme 5). All tri-

a) CUAAC reactions

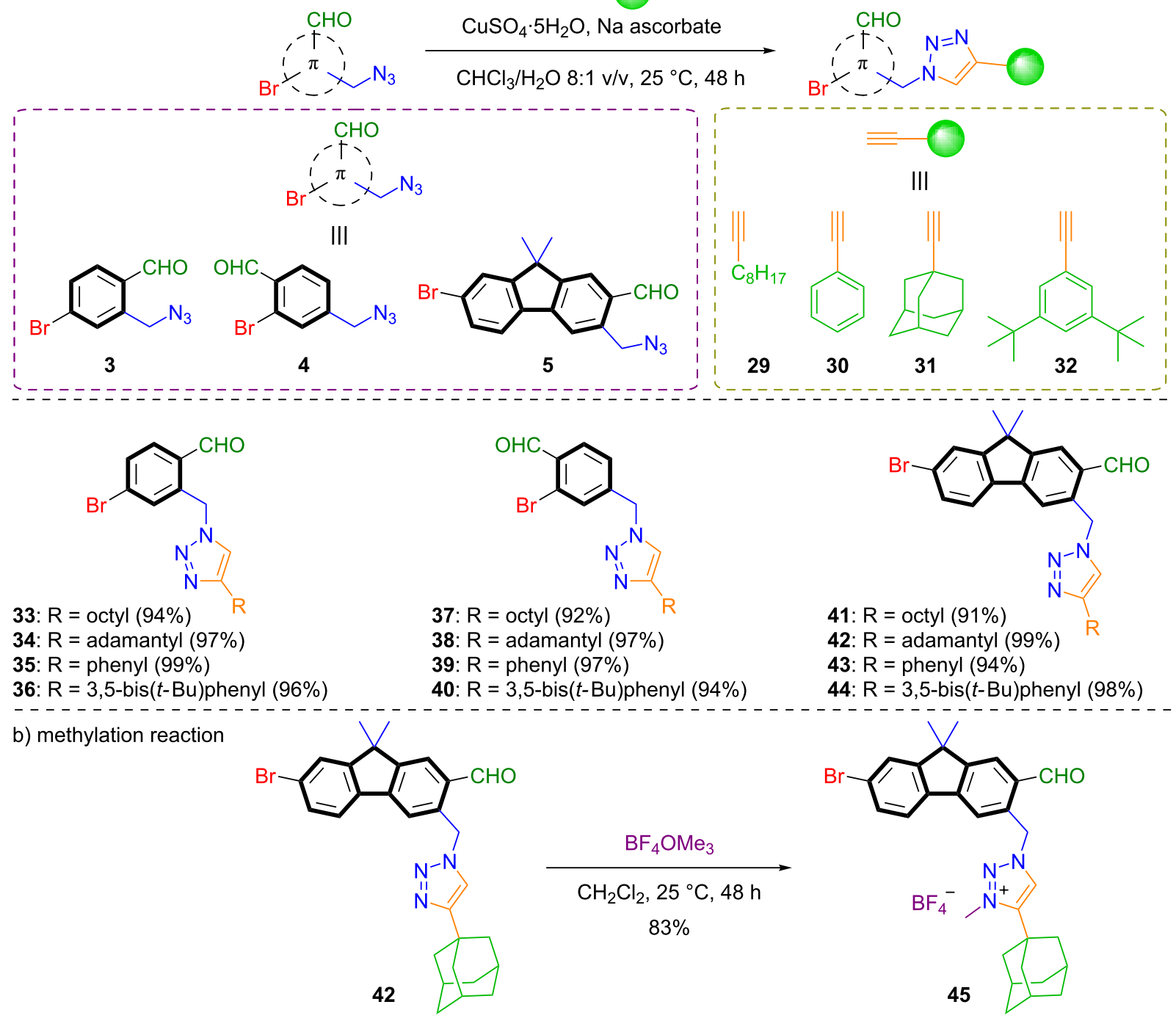

Scheme 5: a) CuAAC reactions of azide-functionalized bromocarbaldehydes 3, 4 and 5 with terminal alkynes to triazoles 33-44. General reaction conditions for CuAAC reactions: Azide (1.00 equiv), terminal alkyne (1.05 equiv), $\mathrm{CuSO}_{4} \cdot 5 \mathrm{H}_{2} \mathrm{O}$ ( 0.1 equiv), sodium ascorbate $\left(0.50\right.$ equiv), $\mathrm{CHCl}_{3}$, $(0.1 \mathrm{M})$ and water $(12.5 \mathrm{mM})$ at $25^{\circ} \mathrm{C}$ for $48 \mathrm{~h}$. b) Methylation reaction of adamantly-substituted triazole 42 with Meerwein's salt (trimethyloxonium tetrafluoroborate). 
azoles 33-44, based on the bromocarbaldehydes $3, \mathbf{4}$, and 5 were successfully isolated in excellent yields of $>90 \%$. As a further model functionalization, the sterically demanding adamantyl substituted triazole $\mathbf{4 2}$ was subjected to a methylation reaction with Meerwein's salt (trimethyloxonium tetrafluoroborate) to deliver the $N$-methylated triazole $\mathbf{4 5}$ in $83 \%$ yield.

\section{Photophysical properties}

Finally, we examined the photophysical properties of both the azides and the triazoles. UV-vis absorption measurements of para-bromobenzaldehyde $\mathbf{3}$ and ortho-bromobenzaldehyde $\mathbf{4}$ as well as the corresponding triazoles $\mathbf{3 3 - 4 0}$ were conducted in chloroform. Intense absorption bands below $270 \mathrm{~nm}$ were observed, which could be attributed to typical $\pi-\pi^{*}$ transitions derived from the single-benzene core. In addition, unstructured absorption bands above $290 \mathrm{~nm}$ were observed, while ortho-derivatives exhibited more broadened bands than the para-derivatives (see Figure 2a and Figures S1-S11 in Supporting Information File 1). The emission spectra for para-bromocarbaldehyde $\mathbf{3}$ and adamantyltriazole $\mathbf{3 4}$ in the solid-state show maxima at $440 \mathrm{~nm}$ (for compound 3) and $416 \mathrm{~nm}$ (for compound 34) (see Figure $2 b$ ). Additionally, fluorescence lifetimes $(\tau)$ of $\mathbf{3}$ and $\mathbf{3 4}$ were determined by time correlated single photon counting (TCSPC), indicating low lifetimes of $2.21 \mathrm{~ns}$ (for compound $\mathbf{3}$ ) and $3.23 \mathrm{~ns}$ (for compound 34) for lower populated species (see Figure S6, Supporting Information File 1). Quantum yields $(\Phi)$ of both derivatives are below $1 \%$ in the solid-state. In chloroform, no luminescence was detected for the para derivatives. All ortho derivatives exhibited luminescence neither in solution nor in the solid-state [73].
These observations for the para- and ortho-bromobenzaldehydes indicate that the phosphorescence is quenched in these systems, yielding only a weak fluorescence. This may be owing to the azide moiety, either as a functional group or as part of the triazole heterocycle. Similar observations were already made for luminescent materials $[74,75]$.

Fluorene derivatives were subjected to photophysical measurements as well. UV-vis absorption spectra of bromofluorenecarbaldehydes 5 and $\mathbf{1 6}$ show intense absorption bands at 331 and $330 \mathrm{~nm}$. Furthermore, adamantyltriazole 42 and the corresponding tetrafluoroborate salt $\mathbf{4 5}$ exhibit similar absorption properties, while the methylated species $\mathbf{4 5}$ shows a comparable slightly red-shifted absorption band (see Figure $3 \mathrm{a}$ and Figures S12-S14 in Supporting Information File 1). Emission measurements of carbaldehydes $\mathbf{5}$ and $\mathbf{1 6}$ revealed that the solid-state emission bands are more blue-shifted than the emission bands in solution (see Figure 3b). Similar observations were made for adamantyltriazole $\mathbf{4 2}$ and tetrafluoroborate salt $\mathbf{4 5}$ with maxima at $510 \mathrm{~nm}$ and $540 \mathrm{~nm}$ (see Figure 3c). However, TCSPC demonstrated that solely fluorescence was observed in all physical states for all investigated compounds with a maximum lifetime $\tau$ of $11.6 \mathrm{~ns}$ for methylated triazole $\mathbf{4 5}$ in chloroform (see Figure 3d). Quantum yields $\Phi$ were determined to be $<1 \%$ for all structures. Further fluorene derivatives - methoxymethyl carbaldehyde $\mathbf{2 3}$, iminium bromide $\mathbf{2 5}$ and ammonium triflate 28 - exhibit intense absorption maxima around $320 \mathrm{~nm}$ (see Figure S13, Supporting Information File 1). For compounds 25 and $\mathbf{2 8}$, the emission maxima in the solid-state were red-shifted compared to the emission bands in chloroform solution (see Figures S31 and S33, Supporting Information File 1). Alde-
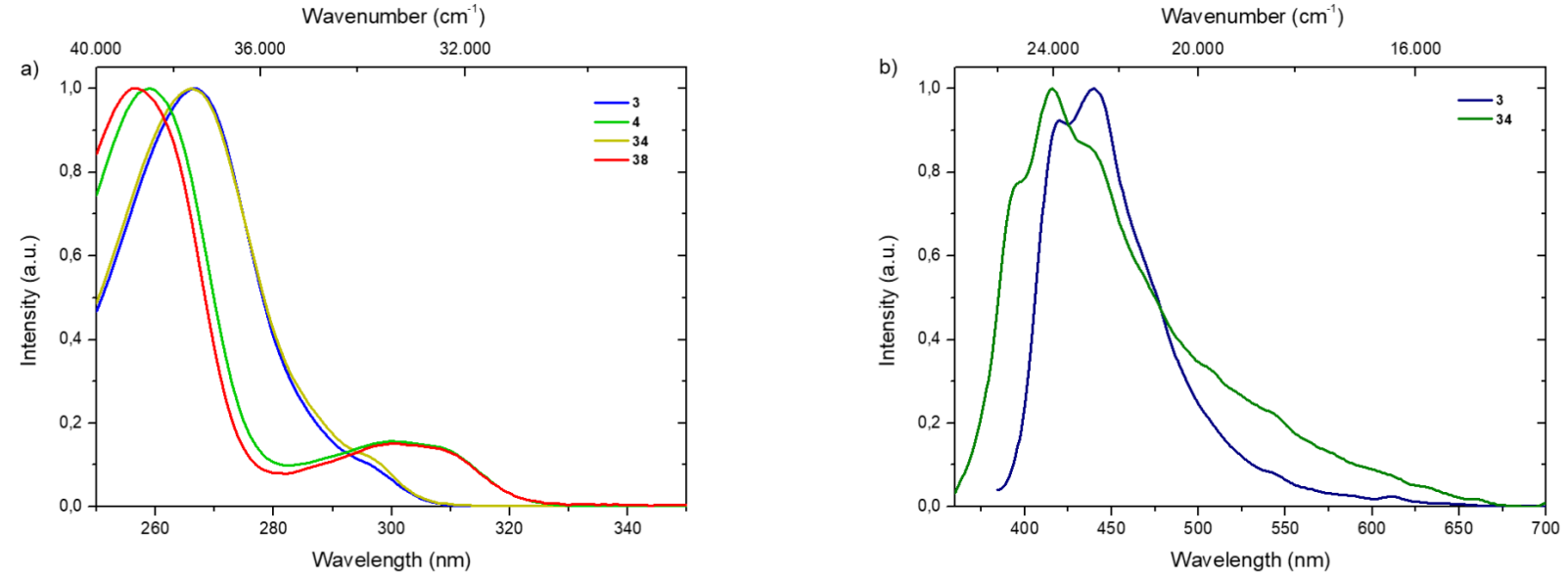

Figure 2: a) Normalized UV-vis absorption spectra of 3 (blue line), 34 (olive line), $\mathbf{4}$ (green line) and $\mathbf{3 8}$ (red line) in $\mathrm{CHCl}_{3}\left(c=10^{-5} \mathrm{~mol}^{-\mathrm{L}^{-1}}\right.$ ) b) Normalized emission spectra of $\mathbf{3}$ (navy line), $\mathbf{3 4}$ (green line) in the solid-state. 

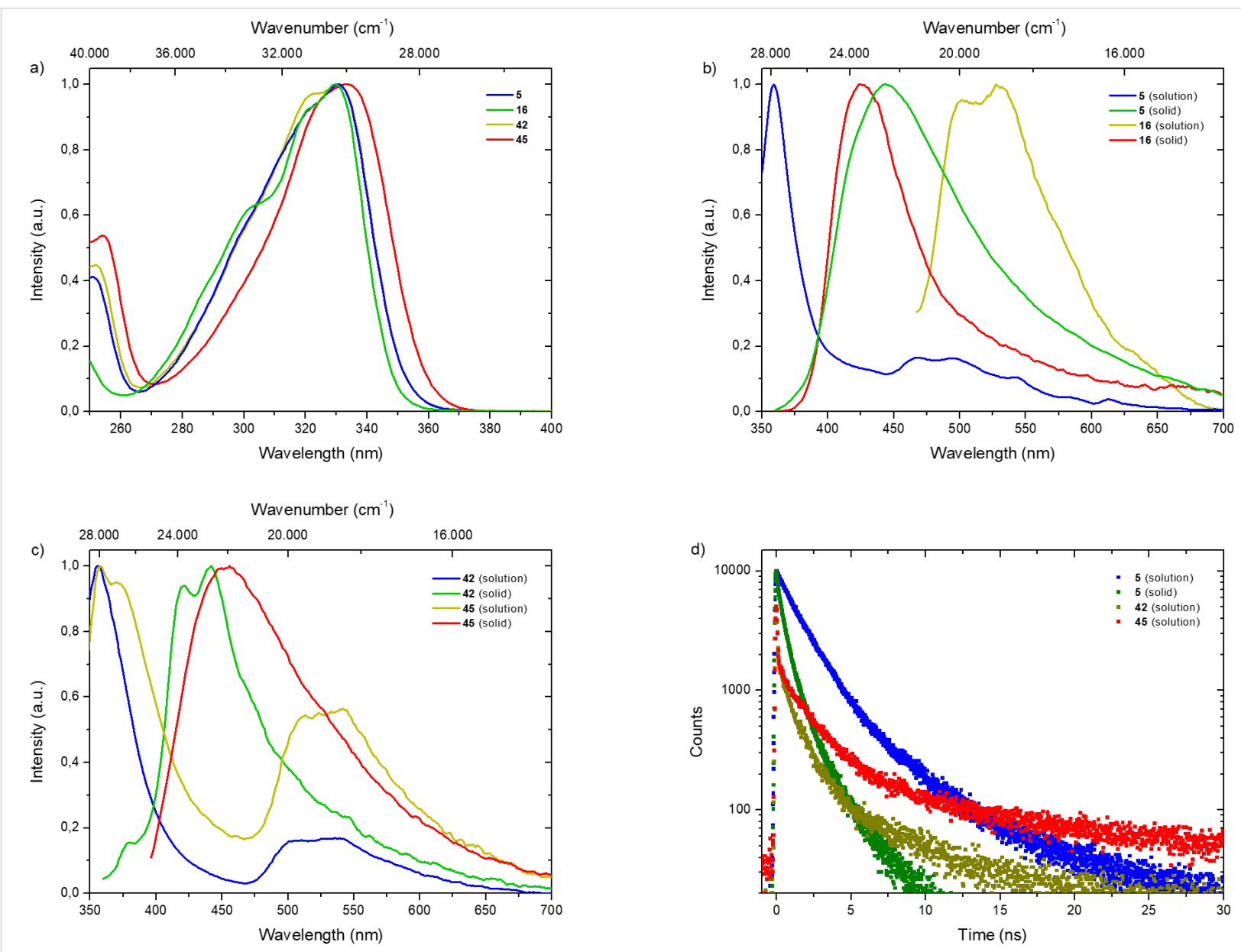

Figure 3: a) Normalized UV-vis absorption spectra of 5 (blue line), 16 (green line), 42 (olive line) and $\mathbf{4 5}$ (red line) in $\mathrm{CHCl}_{3}$. b) Normalized emission spectra of $\mathbf{5}$ (in solution, blue line and in the solid-state, green line) and $\mathbf{1 6}$ (in solution, olive line and in the solid-state, red line). c) Normalized emission spectra of $\mathbf{4 2}$ (in solution, blue line and in the solid-state, green line) and $\mathbf{4 5}$ (in solution, olive line and in the solid-state, red line). d) Time resolved emission decay curves of $\mathbf{5}$ (in solution, blue dots and in the solid-state, green dots), $\mathbf{4 2}$ (in solution, olive dots) and $\mathbf{4 5}$ (in solution, red dots) at $25^{\circ} \mathrm{C}$. In all diluted measurements $\left(c=10^{-5} \mathrm{~mol} \cdot \mathrm{L}^{-1}\right) \mathrm{CHCl}_{3}$ was used as solvent and solutions were sparged with argon for $30 \mathrm{minutes}$.

hyde 23 exhibits a deep violet emission maximum at $360 \mathrm{~nm}$ in chloroform solution and no emission in the solid-state (see Figure S30, Supporting Information File 1). Lifetimes $\tau$ were defined up to $8.66 \mathrm{~ns}$ for iminium bromide $\mathbf{2 5}$, with quantum yields $\Phi$ below 1\% (see Figure S32, Supporting Information File 1). The absence of any long living triplet species in all fluorene derivatives in solution as well as in the solid-state again indicates undesirable quenching events, induced by the azide functionalities, similar to para- and ortho-bromobenzaldehydes.

\section{Conclusion}

In summary, azide-functionalized ortho- and para-bromobenzaldehydes and fluorene derivatives were successfully synthesized. The azide bearing arenes were efficiently linked with even sterically highly demanding alkynes in CuAAC. Initial photophysical investigations of azide-functionalized bromocarbaldehydes and fluorenes revealed that the azide moiety and the triazole heterocycle efficiently quench phosphorescent transi- tions. Efforts of installing other functional groups suitable for covalent connections or modifications of the alkyl bridge between the arene and the azide are underway in our laboratories.

\section{Supporting Information}

\section{Supporting Information File 1}

Detailed experimental procedures, characterization data, photophysical properties, and copies of NMR spectra. [https://www.beilstein-journals.org/bjoc/content/ supplementary/1860-5397-16-139-S1.pdf]

\section{Acknowledgements}

We thank Prof. Dr. Nadja-C. Bigall, Dr. Dirk Dorfs and Pascal Rusch (all from Leibniz University Hannover) for supporting the photophysical measurements. 


\section{ORCID ${ }^{\circledR}$ iDs}

Marius Friedrich - https://orcid.org/0000-0002-7309-5288

Enno Lork - https://orcid.org/0000-0002-0582-9913

Boris J. Nachtsheim - https://orcid.org/0000-0002-3759-2770

\section{Preprint}

A non-peer-reviewed version of this article has been previously published as a preprint https://doi.org/10.26434/chemrxiv.12238967.v1

\section{References}

1. Kabe, R.; Notsuka, N.; Yoshida, K.; Adachi, C. Adv. Mater. (Weinheim, Ger.) 2016, 28, 655-660. doi:10.1002/adma.201504321

2. Tao, Y.; Yang, C.; Qin, J. Chem. Soc. Rev. 2011, 40, 2943-2970. doi:10.1039/c0cs00160k

3. Goushi, K.; Yoshida, K.; Sato, K.; Adachi, C. Nat. Photonics 2012, 6, 253-258. doi:10.1038/nphoton.2012.31

4. Zhang, Q.; Li, B.; Huang, S.; Nomura, H.; Tanaka, H.; Adachi, C. Nat. Photonics 2014, 8, 326-332. doi:10.1038/nphoton.2014.12

5. Chaudhuri, D.; Wettach, H.; van Schooten, K. J.; Liu, S.; Sigmund, E.; Höger, S.; Lupton, J. M. Angew. Chem., Int. Ed. 2010, 49, 7714-7717. doi:10.1002/anie.201003291

6. Chaudhuri, D.; Sigmund, E.; Meyer, A.; Röck, L.; Klemm, P.; Lautenschlager, S.; Schmid, A.; Yost, S. R.; Van Voorhis, T.; Bange, S.; Höger, S.; Lupton, J. M. Angew. Chem., Int. Ed. 2013, 52, 13449-13452. doi:10.1002/anie.201307601

7. Murawski, C.; Leo, K.; Gather, M. C. Adv. Mater. (Weinheim, Ger.) 2013, 25, 6801-6827. doi:10.1002/adma.201301603

8. Baldo, M. A.; O'Brien, D. F.; You, Y.; Shoustikov, A.; Sibley, S.; Thompson, M. E.; Forrest, S. R. Nature 1998, 395, 151-154 doi:10.1038/25954

9. Gao, R.; Mei, X.; Yan, D.; Liang, R.; Wei, M. Nat. Commun. 2018, 9 , 2798. doi:10.1038/s41467-018-05223-3

10. Miao, Q.; Xie, C.; Zhen, X.; Lyu, Y.; Duan, H.; Liu, X.; Jokerst, J. V.; Pu, K. Nat. Biotechnol. 2017, 35, 1102-1110. doi:10.1038/nbt.3987

11. Zhen, X.; Tao, Y.; An, Z.; Chen, P.; Xu, C.; Chen, R.; Huang, W.; Pu, K. Adv. Mater. (Weinheim, Ger.) 2017, 29, 1606665. doi:10.1002/adma.201606665

12. Zhang, G.; Palmer, G. M.; Dewhirst, M. W.; Fraser, C. L. Nat. Mater. 2009, 8, 747-751. doi:10.1038/nmat2509

13. DeRosa, C. A.; Seaman, S. A.; Mathew, A. S.; Gorick, C. M.; Fan, Z.; Demas, J. N.; Peirce, S. M.; Fraser, C. L. ACS Sens. 2016, 1 , 1366-1373. doi:10.1021/acssensors.6b00533

14. Lehner, P.; Staudinger, C.; Borisov, S. M.; Klimant, I. Nat. Commun. 2014, 5, 4460. doi:10.1038/ncomms5460

15. Kwon, M. S.; Lee, D.; Seo, S.; Jung, J.; Kim, J. Angew. Chem., Int. Ed. 2014, 53, 11177-11181. doi:10.1002/anie.201404490

16. Xiao, L.; Fu, H. Chem. - Eur. J. 2019, 25, 714-723. doi:10.1002/chem.201802819

17. Jia, W.; Wang, Q.; Shi, H.; An, Z.; Huang, W. Chem. - Eur. J. 2020, 26, 4437-4448. doi:10.1002/chem.201904500

18. Kasha, M. Chem. Rev. 1947, 41, 401-419. doi:10.1021/cr60129a015

19. Lewis, G. N.; Calvin, M. J. Am. Chem. Soc. 1945, 67, 1232-1233. doi:10.1021/ja01223a513

20. Lewis, G. N.; Kasha, M. J. Am. Chem. Soc. 1944, 66, 2100-2116. doi:10.1021/ja01240a030

21. Lewis, G. N.; Lipkin, D.; Magel, T. T. J. Am. Chem. Soc. 1941, 63, 3005-3018. doi:10.1021/ja01856a043
22. Lower, S. K.; El-Sayed, M. A. Chem. Rev. 1966, 66, 199-241. doi:10.1021/cr60240a004

23. El-Sayed, M. A. J. Chem. Phys. 1963, 38, 2834-2838. doi:10.1063/1.1733610

24. Hirata, S. Adv. Opt. Mater. 2017, 5, 1700116. doi:10.1002/adom.201700116

25. Menning, S.; Krämer, M.; Coombs, B. A.; Rominger, F.; Beeby, A.; Dreuw, A.; Bunz, U. H. F. J. Am. Chem. Soc. 2013, 135, 2160-2163. doi:10.1021/ja400416r

26. Yuan, W. Z.; Shen, X. Y.; Zhao, H.; Lam, J. W. Y.; Tang, L.; Lu, P.; Wang, C.; Liu, Y.; Wang, Z.; Zheng, Q.; Sun, J. Z.; Ma, Y.; Tang, B. Z. J. Phys. Chem. C 2010, 114, 6090-6099. doi:10.1021/jp909388y

27. Zhang, G.; Chen, J.; Payne, S. J.; Kooi, S. E.; Demas, J. N.; Fraser, C. L. J. Am. Chem. Soc. 2007, 129, 8942-8943. doi:10.1021/ja0720255

28. Xu, J.; Takai, A.; Kobayashi, Y.; Takeuchi, M. Chem. Commun. 2013, 49, 8447-8449. doi:10.1039/c3cc44809f

29. Schulze, M.; Steffen, A.; Würthner, F. Angew. Chem., Int. Ed. 2015, 54 1570-1573. doi:10.1002/anie.201410437

30. Hirata, S.; Totani, K.; Yamashita, T.; Adachi, C.; Vacha, M. Nat. Mater. 2014, 13, 938-946. doi:10.1038/nmat4081

31. Pan, Z.; Lu, Y.-Y.; Liu, F. Nat. Mater. 2012, 11, 58-63. doi:10.1038/nmat3173

32. Tong, B.; Mei, Q.; Wang, S.; Fang, Y.; Meng, Y.; Wang, B. J. Mater. Chem. 2008, 18, 1636-1639. doi:10.1039/b800977e

33. Liu, Z. W.; Guan, M.; Bian, Z. Q.; Nie, D. B.; Gong, Z. L.; Li, Z. B.; Huang, C. H. Adv. Funct. Mater. 2006, 16, 1441-1448. doi:10.1002/adfm.200600099

34. Zhao, J.; Chen, K.; Hou, Y.; Che, Y.; Liu, L.; Jia, D. Org. Biomol. Chem. 2018, 16, 3692-3701. doi:10.1039/c8ob00421h

35. Forni, A.; Lucenti, E.; Botta, C.; Cariati, E. J. Mater. Chem. C 2018, 6 , 4603-4626. doi:10.1039/c8tc01007b

36. Baroncini, M.; Bergamini, G.; Ceroni, P. Chem. Commun. 2017, 53, 2081-2093. doi:10.1039/c6cc09288h

37. Mukherjee, S.; Thilagar, P. Chem. Commun. 2015, 51, 10988-11003. doi:10.1039/c5cc03114a

38. Shi, H.; Song, L.; Ma, H.; Sun, C.; Huang, K.; Lv, A.; Ye, W.; Wang, H.; Cai, S.; Yao, W.; Zhang, Y.; Zheng, R.; An, Z.; Huang, W. J. Phys. Chem. Lett. 2019, 10, 595-600. doi:10.1021/acs.jpclett.8b03712

39. Li, J.-A.; Zhou, J.; Mao, Z.; Xie, Z.; Yang, Z.; Xu, B.; Liu, C.; Chen, X.; Ren, D.; Pan, H.; Shi, G.; Zhang, Y.; Chi, Z. Angew. Chem., Int. Ed. 2018, 57, 6449-6453. doi:10.1002/anie.201800762

40. Xiong, Y.; Zhao, Z.; Zhao, W.; Ma, H.; Peng, Q.; He, Z.; Zhang, X.; Chen, Y.; He, X.; Lam, J. W. Y.; Tang, B. Z. Angew. Chem., Int. Ed. 2018, 57, 7997-8001. doi:10.1002/anie.201800834

41. Gu, L.; Shi, H.; Miao, C.; Wu, Q.; Cheng, Z.; Cai, S.; Gu, M.; Ma, C.; Yao, W.; Gao, Y.; An, Z.; Huang, W. J. Mater. Chem. C 2018, 6, 226-233. doi:10.1039/c7tc04452f

42. Cai, S.; Shi, H.; Zhang, Z.; Wang, X.; Ma, H.; Gan, N.; Wu, Q.; Cheng, Z.; Ling, K.; Gu, M.; Ma, C.; Gu, L.; An, Z.; Huang, W. Angew. Chem., Int. Ed. 2018, 57, 4005-4009. doi:10.1002/anie.201800697

43. Cai, S.; Shi, H.; Tian, D.; Ma, H.; Cheng, Z.; Wu, Q.; Gu, M.; Huang, L.; An, Z.; Peng, Q.; Huang, W. Adv. Funct. Mater. 2018, 28, 1705045 doi:10.1002/adfm.201705045

44. Cai, S.; Shi, H.; Li, J.; Gu, L.; Ni, Y.; Cheng, Z.; Wang, S.; Xiong, W.-w.; Li, L.; An, Z.; Huang, W. Adv. Mater. (Weinheim, Ger.) 2017, 29 , 1701244. doi:10.1002/adma.201701244 
45. Yang, Z.; Mao, Z.; Zhang, X.; Ou, D.; Mu, Y.; Zhang, Y.; Zhao, C.; Liu, S.; Chi, Z.; Xu, J.; Wu, Y.-C.; Lu, P.-Y.; Lien, A.; Bryce, M. R. Angew. Chem., Int. Ed. 2016, 55, 2181-2185. doi:10.1002/anie.201509224

46. Gong, Y.; Chen, G.; Peng, Q.; Yuan, W. Z.; Xie, Y.; Li, S.; Zhang, Y.; Tang, B. Z. Adv. Mater. (Weinheim, Ger.) 2015, 27, 6195-6201. doi:10.1002/adma.201502442

47. An, Z.; Zheng, C.; Tao, Y.; Chen, R.; Shi, H.; Chen, T.; Wang, Z.; Li, H.; Deng, R.; Liu, X.; Huang, W. Nat. Mater. 2015, 14, 685-690. doi:10.1038/nmat4259

48. Yu, Z.; Wu, Y.; Peng, Q.; Sun, C.; Chen, J.; Yao, J.; Fu, H. Chem. - Eur. J. 2016, 22, 4717-4722. doi:10.1002/chem.201600300

49. Chen, X.; Xu, C.; Wang, T.; Zhou, C.; Du, J.; Wang, Z.; Xu, H.; Xie, T.; Bi, G.; Jiang, J.; Zhang, X.; Demas, J. N.; Trindle, C. O.; Luo, Y.; Zhang, G. Angew. Chem., Int. Ed. 2016, 55, 9872-9876. doi:10.1002/anie.201601252

50. Lin, Z.; Kabe, R.; Nishimura, N.; Jinnai, K.; Adachi, C. Adv. Mater. (Weinheim, Ger.) 2018, 30, 1803713. doi:10.1002/adma.201803713

51. Li, D.; Lu, F.; Wang, J.; Hu, W.; Cao, X.-M.; Ma, X.; Tian, H. J. Am. Chem. Soc. 2018, 140, 1916-1923. doi:10.1021/jacs.7b12800

52. Kabe, R.; Adachi, C. Nature 2017, 550, 384-387. doi:10.1038/nature24010

53. Gan, N.; Wang, X.; Ma, H.; Lv, A.; Wang, H.; Wang, Q.; Gu, M.; Cai, S.; Zhang, Y.; Fu, L.; Zhang, M.; Dong, C.; Yao, W.; Shi, H.; An, Z.; Huang, W. Angew. Chem., Int. Ed. 2019, 58, 14140-14145. doi:10.1002/anie.201907572

54. Yang, J.; Ren, Z.; Chen, B.; Fang, M.; Zhao, Z.; Tang, B. Z.; Peng, Q.; Li, Z. J. Mater. Chem. C 2017, 5, 9242-9246. doi:10.1039/c7tc03656f

55. Shimizu, M.; Shigitani, R.; Nakatani, M.; Kuwabara, K.; Miyake, Y.; Tajima, K.; Sakai, H.; Hasobe, T. J. Phys. Chem. C 2016, 120 , 11631-11639. doi:10.1021/acs.jpcc.6b03276

56. Xie, Y.; Ge, Y.; Peng, Q.; Li, C.; Li, Q.; Li, Z. Adv. Mater. (Weinheim, Ger.) 2017, 29, 1606829. doi:10.1002/adma.201606829

57. Bergamini, G.; Fermi, A.; Botta, C.; Giovanella, U.; Di Motta, S.; Negri, F.; Peresutti, R.; Gingras, M.; Ceroni, P. J. Mater. Chem. C 2013, 1, 2717-2724. doi:10.1039/c3tc00878a

58. Bolton, O.; Lee, K.; Kim, H.-J.; Lin, K. Y.; Kim, J. Nat. Chem. 2011, 3, 205-210. doi:10.1038/nchem.984

59. Yu, Y.; Kwon, M. S.; Jung, J.; Zeng, Y.; Kim, M.; Chung, K.; Gierschner, J.; Youk, J. H.; Borisov, S. M.; Kim, J. Angew. Chem., Int. Ed. 2017, 56, 16207-16211. doi:10.1002/anie.201708606

60. Kwon, M. S.; Jordahl, J. H.; Phillips, A. W.; Chung, K.; Lee, S.; Gierschner, J.; Lahann, J.; Kim, J. Chem. Sci. 2016, 7, 2359-2363. doi:10.1039/c5sc03986j

61. Kwon, M. S.; Yu, Y.; Coburn, C.; Phillips, A. W.; Chung, K.; Shanker, A.; Jung, J.; Kim, G.; Pipe, K.; Forrest, S. R.; Youk, J. H.; Gierschner, J.; Kim, J. Nat. Commun. 2015, 6, 8947. doi:10.1038/ncomms9947

62. Lee, D.; Jung, J.; Bilby, D.; Kwon, M. S.; Yun, J.; Kim, J. ACS Appl. Mater. Interfaces 2015, 7, 2993-2997. doi:10.1021/am5087165

63. Bolton, O.; Lee, D.; Jung, J.; Kim, J. Chem. Mater. 2014, 26, 6644-6649. doi:10.1021/cm503678r

64. Goudappagouda; Manthanath, A.; Wakchaure, V. C.; Ranjeesh, K. C.; Das, T.; Vanka, K.; Nakanishi, T.; Babu, S. S. Angew. Chem., Int. Ed. 2019, 58, 2284-2288. doi:10.1002/anie.201811834
65. Kuila, S.; Rao, K. V.; Garain, S.; Samanta, P. K.; Das, S.; Pati, S. K.; Eswaramoorthy, M.; George, S. J. Angew. Chem., Int. Ed. 2018, 57, 17115-17119. doi:10.1002/anie.201810823

66. Yu, Z.; Wu, Y.; Xiao, L.; Chen, J.; Liao, Q.; Yao, J.; Fu, H. J. Am. Chem. Soc. 2017, 139, 6376-6381. doi:10.1021/jacs.7b01574

67. Huang, C.-H.; Wu, P.-J.; Chung, K.-Y.; Chen, Y.-A.; Li, E. Y.; Chou, P.-T. Phys. Chem. Chem. Phys. 2017, 19, 8896-8901. doi:10.1039/c7cp00074j

68. Ventura, B.; Bertocco, A.; Braga, D.; Catalano, L.; d'Agostino, S.; Grepioni, F.; Taddei, P. J. Phys. Chem. C 2014, 118, 18646-18658. doi:10.1021/jp5049309

69. Koch, M.; Perumal, K.; Blacque, O.; Garg, J. A.; Saiganesh, R.; Kabilan, S.; Balasubramanian, K. K.; Venkatesan, K. Angew. Chem., Int. Ed. 2014, 53, 6378-6382. doi:10.1002/anie.201402199

70. Göbel, D.; Clamor, N.; Nachtsheim, B. J. Org. Biomol. Chem. 2018, 16, 4071-4075. doi:10.1039/c8ob01072b

71. Göbel, D.; Clamor, N.; Lork, E.; Nachtsheim, B. J. Org. Lett. 2019, 21, 5373-5377. doi:10.1021/acs.orglett.9b01350

72. Göbel, D.; Duvinage, D.; Stauch, T.; Nachtsheim, B. J. J. Mater. Chem. C 2020. doi:10.1039/d0tc00776e

73. Sarkar, S.; Hendrickson, H. P.; Lee, D.; DeVine, F.; Jung, J.; Geva, E.; Kim, J.; Dunietz, B. D. J. Phys. Chem. C 2017, 121, 3771-3777. doi:10.1021/acs.jpcc.6b12027

74. Xie, S.; Proietti, G.; Ramström, O.; Yan, M. J. Org. Chem. 2019, 84, 14520-14528. doi:10.1021/acs.joc.9b02050

75. Lord, S. J.; Lee, H.-I. D.; Samuel, R.; Weber, R.; Liu, N.; Conley, N. R.; Thompson, M. A.; Twieg, R. J.; Moerner, W. E. J. Phys. Chem. B 2010, 114, 14157-14167. doi:10.1021/jp907080r

\section{License and Terms}

This is an Open Access article under the terms of the Creative Commons Attribution License (http://creativecommons.org/licenses/by/4.0). Please note that the reuse, redistribution and reproduction in particular requires that the authors and source are credited.

The license is subject to the Beilstein Journal of Organic Chemistry terms and conditions:

(https://www.beilstein-journals.org/bjoc)

The definitive version of this article is the electronic one which can be found at: doi:10.3762/bjoc.16.139 